\title{
THE CHALLENGES OF INTERNATIONAL AIR LAW PRINCIPLES IN GLOBALIZATION ERA
}

\author{
Adi Kusumaningrum ${ }^{1}$ \\ ${ }^{1}$ Faculty of Law, Brawijaya University \\ Email: adikusumaningrum@gmail.com
}

Submitted: 2017-09-29 | Accept: 2017-10-19

\begin{abstract}
The concept of state's sovereignty had become one of debatable issues within the international law studies during the $20^{\text {th }}$ century. International air transport has always been one of the most regulated of industries of globalization. Therefore, airspace sovereignty no escape from the challenges of globalization. This regulatory system has been changing recently because of worldwide initiative that have paved the way for enhancing air transport liberalization. This is why numerous models have been hypothesized for a new (multilateral) aviation order to supersede bilateralism, which still remains the primary vehicle for liberalizing international air transport service for most states. This study intends to discuss about the basic principles of international airspace law that frequently facing challenges in the globalization era. In the last few decades is that the economic aspects of airspace sovereignty have dominated change, or the lack thereof, in the international air sovereignty regime. In addition, there are many challanges in politic and law. In the context of Indonesia airspace challanges, in the near future, it is needed to revitalize the function of the strong regulation. This can be started by re-evaluating the regulations that is continued by the arrangement of the anatomy of the setting that is comprehensive, systematic, careful, effective and also efficient based on two importance that are prosperity and security.
\end{abstract}

Keywords: Challanges, international basic principle, airspace law, globalization era

\section{INTRODUCTION}

The concept of national sovereignty has been dramatically changed after World War I ended. Several new perspectives upon sovereignty occurred due to this event. The normative ideas that previously being preserved, had been set aside. This fact proved that the traditional concept of sovereignty could no longer accommodate the situation in globalization and democratic era. ${ }^{1}$ The concept of nation's sovereignty had become one of debatable issues within the international law studies during the $20^{\text {th }}$ century. Moreover, the studies upon sovereignty is done based on various approaches, it does not only come from legal and international relation approaches, but also based on anthropology and sociology. ${ }^{2}$ Many challenges arose against

\footnotetext{
${ }^{1}$ Stephen D. Krasner, 'Abiding Sovereignty', (2000) 222 International Political Science Review / Revue internationale de science politique, 234.

2 See Thomas Blom Hansen \& Finn Steputat, 'Sovereignty Revisited', (2006) 35 Annual Review of Anthropology, 295-315.
} 
the concept of nation's sovereignty either from the aspect of politic, economy, law, or even socio-cultural and environment.

One of the setbacks of nation's sovereignty in terms of airspace is the development into globalization era. International air transportation is one of the most policed sector within the industrial world in globalization era. Traditionally, this sector has been regulated based on Chicago Convention 1944 by virtue of bilateral air services, in which countries are allowed to trade the freedom of airspace among them. ${ }^{3}$ Unfortunately, the regulation had been repealed because of the initiative to open and liberate the air transportation.

Many hypothesis model of new order flight (multilateral), which substitute the bilateral system of airspace law, aim the liberty of international air transportation service to all countries as their main objective. $^{4}$ It is emphasized by Stepen M. Shrewsbury, the economic aspect of airspace sovereignty tend to dominate any following changes of airspace sovereignty in the future. The pros of "laissez-faire" will actively advocate the freedom of airspace and free competition. ${ }^{5}$ The challenges

\footnotetext{
${ }^{3}$ Francesco Gaspari, 'The EU Air Transport Liberalization and Re-Regulatin', (2011) 112 International and Comparative Law Review, 6. ${ }^{4}$ Ibid.

5 Stepen M. Shrewsbury, 'September $11^{\text {th }}$ and The Single European Sky: Developing Concepts of Airspace Sovereignty', (2003) 68115 Journal of Air Law and Commerce. Stephen stated that there are still a lot of countries in the world who hold on absolute sovereignty of territory. He said that 256
}

occurred during the evolution process of airspace sovereignty does not only come from economic aspect but also from many other factors along with the evolution of nation's sovereignty based on the international law.

This study intends to discuss about the basic principles of international airspace law that frequently facing challenges in the globalization era. These basic principles are mentioned in Article 1 of Chicago Convention 1944 on International Civil Aviation. This article contributes huge role and holds the highest authority in managing air transportation in a country according to the sovereignty principle of "complete" and "exclusive". 6 The role of a country, as the highest authority, in managing air transportation is mentioned in Article 6 Chicago Convention 1944. This article set a juridical consequence that, de jure, the airspace of each country is "closed" for foreigners, unless the concerned has "opened", de facto. Brian F. Havel highlighted his statement that Article 6 is the perfect logic of the "restriction" mentioned

globalization and sovereignty is considered as dichotomy.

6 System that generates from this article is later known as treaditional system. See Erwin von den Steinen, National Interest and International Aviation, (The Netherlands: Kluwer Law International, 2006). See also Hussein Kassim and Handley Stevens, Air Transport and The Eropean Union: Europeanization and its Limit, (Palgrave Macmillan-UK, 2010). See also Paul Stephen Dempsey and Andrew R. Goetz, Airline deregulation and laissez-faire mythology, (Connecticut-London: Quorum Books, 1992). 
in Article 1 of Convention, made under the importance of nation's safety and defense.

\section{LEGAL MATERIALS METHODS}

AND

The type of this research is a normative legal research, which uses a constitutional approach in the form of a juridical normative study. Legal materials used in this paper are primary as well as secondary legal materials. This paper mostly used its legal analyses based on Chicago Convention 1944 on International Civil Aviation. Secondary materials were taken from academic journals as well as other legal sources.

Using the statute and conceptual approaches, this paper is divided into several parts. First part is introduction, which elaborates the changes in national sovereignty concept in globalization era. It further discuss the challenges faced by nation state in globalization era, especially in regulating air transportation above the sovereing territory. The paper ended by conclusion which addressed legal problems posed in this paper

\section{RESULTS AND DISCUSSIONS}

1. Basic Principles of International Airspace Law as the Implication of Nation's Airspace Sovereignty

\footnotetext{
John Cobb Cooper identified four basic principles in the guidance of
}

International Airspace Law, those are: a) Territorial Sovereignty; b) National Airspace; c) Freedom of the Seas and d) National Aircraft. ${ }^{7}$ Territorial Sovereignty is the nation's sovereignty that allows country to gain unilateral and absolute right to give permission or restrict anything coming into the area in their territory, as well as the right to control any activities taken place within the territory. National Airspace is about the three dimension of the territory belongs to one sovereign country, it includes the airspace above the land territory along with the territorial sea and internal waters area. While Freedom of Sea is the principle about the navigation in the surface of open sea and flight above the open sea that is available for all countries. The last, National Aircraft is the national principle for aircraft that specified similarly as for the ships in maritime law. ${ }^{8}$

The abovementioned basic principles by Cooper provide "specific right" for countries, especially in airspace. Niels van Anterpen in his book titled "Cross Border Provision of Air Navigation Services with Spesific Reference ro Europe" explicated the principles of international airspace law that includes: 1) country, territory, and air territory; 2) sovereignty, jurisdiction, and

\footnotetext{
${ }^{7}$ John Cobb Cooper, 'Backgrounds of Internasional Public Air Law', (1967) 13 Yearbook of Air and Space Law, 1.

${ }^{8}$ Ibid
} 
national authority delegation. ${ }^{9} \quad$ The researcher will discuss the basic principles of international airspace law as follows:

\section{Country, Territory, and Air Territory}

Based on the pure theory of Law by the concept of Kalsen emphasizes that country as the personification of national law order that occupies a territory with particular border. ${ }^{10}$ In his book "General Theory of Law and State”, Hans Kensen stated that the validity and effectiveness of national law order does not only applied to the width and the length of its country, but also to the depth and height. ${ }^{11}$ It is supported by Willoughby by saying that the existence of a country depends on the its right upon the territory it belongs. Furthermore, Kelsen explained that territory is a zone where a law order is applied throughout the whole area. The territory of a country is the area where law order, called nation, is applied.

Territory, as mentioned in Article 1 Chicago Convention 1994, is further regulated in Article 2 of the Convention which includes the policy related to lands area and territorial waters.

Based on Article 2 Chicago Convention 1994, it can be concluded that the definition of air territory as the airspace above lands and territorial waters aside of it that is

\footnotetext{
${ }^{9}$ Niels van Antwerpen, Cross Border Provision of Air Navigation Services with Spesific Reference ro Europe , (The Netherland: Kluwer Law International, 2010), 18.

${ }^{10}$ Hans Kelsen, Teori Umum tentang Hukum dan Negara, translated by Raisul Muttaqien, (Bandung: Nusa Media, 2011), 297.

${ }^{11}$ Ibid., 309.

regulated under the authority/sovereignty, protection, and the policy of one country. According to Boer Mauna, sea is the extension of land, therefore, the air territory of a country is determined based on the country's borderline in the land and sea. ${ }^{12}$ The definitions of air territory above has proven the existence of horizontal borderline of air territory. Meanwhile, there is still no any agreement from the international society upon the vertical borderline of air territory. This is because there are various theories that being used to support each opinion about the case (theory of airspace and outer space border).

Horizontal borderline of air territory above a wide superjacent of sea devide and reflect the law regime of airspace above the different sea territory or zone. In order to understand the regime of air space law above the different water area or zone, the sources of Maritime Law is ought to comprehend for Chicago Convention 1944 does not provide such explanation. The common source of modern Maritime Law is United Nations Convention on the Law of the Sea (UNCLOS). It does not only provide the common code law on the sea, but also contain the progressive development of international law as the main concern of Article 13.1.a Charter of UN. ${ }^{13}$ The subject

\footnotetext{
${ }^{12}$ Boer Mauna, Pengertian, Peranan Dan Fungsi Dalam Era Dinamika Global. (Bandung: PT Alumni, 2003), 379.

${ }^{13}$ Article 13.1.a of UN Charter contains the essence of international law in developing international
} 
of sea territory is further mentioned specifically in Article 2 UNCLOS, which is relevant to the implementation of Chicago Convention.

1) Open Sea

Article 86 of UNCLOS regulated the implementation of BAB policy about open sea. This article mentions that the requirement of this chapter is valid to all part of the sea such as the sea territory or internal waters of a country, or archipelagic waters in archipelagic state, except for Exclusive Economic Zone. This article does not reduce any freedom of all countries in exclusive Economic Zone as regulated in article 58 .

The freedom of open sea includes the freedom of navigation and overflight, and no countries could legitimately claim or declare themselves as the subject of open sea as their part of sovereignty. In other words, open sea along with the air space is out of the country's jurisdiction. Even so, there are still regulation applied to the airspace above the open sea in order to maintain the safety of flights taken place in the area. The thirds sentence of Article 12 of Chicago Convention decrees that above the open sea, the statutory regulation shall be obeyed under the decree of this Convention. This is indeed the authority of the Board of ICAO

cooperation in politics and enhance the international law along with the codes. These are some of the responsibilities, duties, and authorities of UN General Assembly, as stated in Article 13 of Un Charter. to determine the International Standard as mentioned in Annex 2 for Chicago Convention. It contains the regulation of fight and aircraft maneuver above the open sea. UNCLOS also contain two references regarding to 'aircraft' in Chapter VII in open sea, those are about 'skyjacking' and 'chasing. ${ }^{14}$

2) Contiguous Zone

Article 33 of UNCLOS also regulates the contiguous zone. According to Ruwantissa Abeyratne, practically, this requirement means has not been signed in terms of its theory and/or its practice. The enactment of this requirement intends to police every act done by foreign aircraft above the contiguous zone, including the interception of an aircraft to land on the closest airport.

3) Cannel that is used for Air Navigation

Regarding to this part, there are several articles in UNCLOS that is relevant as the legal fundamental for the law enforcement in this zone, those are: Article 37,38, and 39 (3) of UNCLOS. Article 37and 38 of UNCLOS regulate te requirement of Transit Traffic. Meanwhile

\footnotetext{
${ }^{14}$ Both of these terms are not relevant to Chicago Convention, but it shall be remembered that skyjacking can theoretically take place in open sea or other areas out of the jurisdiction of countries by the flight crew or passenger to the plane or other plane. This action never been recorded. The right of "hot persuit" even less relevant to civil aviation for this right can only be executed by a fighter or military aircraft or other type of aircraft that served under the government.
} 
Article 39 (3) determines the duty of air craft in transit traffic.

4) Archipelagic Waters

Archipelagic state as it is governed in PART IV UNCLOS starts from Article 4654. Article 46 defines that archipelagic state means a state constituted wholly by one or more archipelagos and may include other islands. The legal status of archipelagic waters, of the air space over archipelagic waters of archipelagic waters is drawn in Article 49 UNCLOS 1982. According to Article 49 mentioned above, the sovereignty of an archipelagic state covers the airspace beyond the archipelagic waters (regardless of their depth or distance from the coast) as well as to their seabed and subsoil, and the resources contained therein.

5) Exclusive Economic Zone

The specific legal regime of exclusive economic zone is stated in Article 55 UNCLOS 1982 which further determines that exclusive economic zone is an area beyond and adjacent to the territorial sea, subject to the specific legal regime established in this Part, under which the rights and jurisdiction of the coastal state and the rights and freedoms of other states, governed by the relevant provisions of this Convention. The breadth of exclusive economic zone governed in Article 57 cannot extend than 200 nautical miles from the baselines from which the breadth of the territorial sea is measured. In addition, Article 60 (1) UNCLOS 1982 determines 260 that in exclusive economic zone, a coastal state has exclusive rights of coastal state.

6) Continental Shelf

Continental shelf is governed in PART VII from Article 76-85. The continental shelf of a coastal state comprises the seabed and the subsoil of the submarine areas that extend beyond its territorial sea throughout the natural prolongation of its land territory to the outer edge of the continental margin, or to a distance of 200 nautical miles from the baselines from which the breadth of the territorial sea is measured, where the outer edge of the continental margin does not extend up to that distance. The decision of continental shelf shall not extend beyond 350 nautical miles from the baselines where the territorial sea is measured and shall not extend beyond 100 nautical miles from the isobaths of 2.500 meter, which is a line connecting the depth of 2.500 meter.

\section{Air Sovereignty, Jurisdiction and \\ National Authority Delegating}

International law is based on the state concept. State at its turn, is depend on the sovereignty base, where the external dimension sovereignty said that state supreme as a legal person, meanwhile internal sovereignty stated that the supreme of the governmental institutions ${ }^{15}$. Sometimes, sovereignty is defined as

\footnotetext{
15 Malcolm N. Shaw, International Law, Fifth Edition, (Cambridge: Grotius Publications Limited, 2008).
} 
jurisdiction. Sovereignty refers to the legal personality of state, whereas jurisdiction specifically refers to the aspects of substance, special right, claims, liberties and power of state. ${ }^{16}$ Sovereignty refers to the external dimension, in which a state as an actor playing in international level that has statehood, while jurisdiction refers to the internal dimension from a sovereign entity as a principle of a state in rule making and enforcement powers. The jurisdiction is divided into jurisfaction, which is the power to make constitution and construe the constitution, and jurisfaction as a power to reconstruct the constitution, law implementation, verdict and punishment.

Article 1 of Chicago Convention 1944 governs that contracting states of convention admit that every state has its own complete sovereignty and exclusive airspace above its territory. This article strengthens the state sovereignty of airspace, both internal and external. External sovereignty is related to the state status as an international law subject, as a freedom state, which is the requirement to be a signatory state of Convention. On the other side, internal sovereignty is related to the state jurisdiction inside the national area, where there is no scheduled air service that operates through or inside the state territory, except there is a special permission or the other state

\footnotetext{
${ }^{16}$ Ian Brownlie, Principles of Public International Law, Ninth Edition, (Oxford: Clarendon Press, 2000), 106.
}

authorization and according to the rule, a country exclusively master the airspace over its territorial area.

It gives a chance to the states to control the marketing access and protect the internal market and its airline toward international airspace market, from and through territory area.

Article 5 of Chicago Convention 1944 confirms about non-scheduled airline rights of the states aircraft (term used to mention the main convention subject) to make flight across or stop continuously without obtaining prior permission. Nevertheless, article 6 requires states to obtain permission from the contracting state or their scheduled air service. In addition, article 7 of Convention Chicago 1944 determines cabotage as a practice component of Chicago Convention in order to meet the sovereignty principle. All international Civil Aviation system nowadays is based on Article 1 Chicago Convention 1944, as well as Article 5, 6, and 7 of Convention.

\section{Right of Over flight and Traffic Right}

Right of over flight ${ }^{17}$ and traffic right governed in Chicago Convention 1944 related to the type or aircraft is as follows:

\footnotetext{
${ }^{17}$ In international Aviation Law, the definition of traffic right can be found in Article 5 and 6 Chicago Convention 1944 governing about non scheduled flight and scheduled flight, as well as in International Air Service Transit Agreement and International Air Transport Agreement dated at 7 December 1944.
} 
a. Scheduled aircraft (Article 6 Chicago Convention 1944)

Article 6 basically discusses about foreign aircraft that make flight must obtain a permission from the country where it flies. It is understandable since there may be a race with national flights if there is scheduled flight. In order to avoid that kind of condition, then permission is really needed. Besides, scheduled flight is also governed in International Air Service Transit Agreement and International Air Transport Agreement dated at 7 December 1944. ${ }^{18}$

Regarded to Article 6 (scheduled aircraft), the contracting states agree to make a separated agreement which is multilateral scheduled of independent flight exchange, that is International Air Services Transit Agreement or usually known as Two Freedom Agreement and International Air Transport Agreement or usually known as Five Freedom Agreement which each of them is discussed in separated part.

b. Non-scheduled aircraft (Article 5 Chicago Convention 1944)

In non-scheduled aircraft, as it is regulated in Article 5, there are two categories which include (i) right to pass and right to land for non-traffic purpose, for

\footnotetext{
${ }^{18}$ The rule stated in article 6 is actually about the failure of Chicago Convention to find formula for multilateral exchange of traffic rights. Therefore, this Article 6 becomes "is therefore in essence a character for today's existing bilateralism in regulation of scheduled services".
}

example technical business and fuel filling and (ii) right in the carriage of passengers and so on, yet must obey the rule, requirement and limit made. According to Nicolas Matte, article 5 is inspired by liberal spirit. Matte said "Article 5 is inspired by relatively liberal spirit and is he basis for more liberal regulatory regime for non scheduled services and flight". This article 5 is actually a limitation of a state sovereignty in the airspace over it, as it is mentioned in Article 1 Chicago Convention 1944 that: every country has its own wholly and exclusive sovereignty on the airspace over it.
c. State aircraft (Article 3 (c) Chicago Convention 1944)

The stipulation of article 3 (c) Chicago Convention 1944 said that state aircraft is forbidden to fly on the other area without right based on the specific agreement or other way, and obey regulations stipulated in that agreement. That regulation restricts other states airspace breach. Article 3 (c) gives specifications of breach restriction of airspace which is not only by civil aircraft, but also state aircraft, both fly or land on the other airspace state without permission stated in certain agreement. From this article, it can be concluded that breach done by foreign aircraft (civil or military), both fly to enter airspace area or land on the other states, as a breach toward state sovereignty over the whole and exclusive airspace. 
d. Pilotless aircraft ( Article 8 Chicago Convention 1944)

The stipulation of Article 8 Chicago Convention 1944, stated that pilotless aircraft is forbidden to fly over the contracting state airspace without special permission, thus, this kind of breach toward this regulation, the contracting state can do interception. In doing interception, even though a state has a 'full' and 'exclusive' airspace sovereignty over the territorial area, states cannot deport (pursue) commercial aircraft lost from its flight area. The international law, especially international civil aviation, admits that the right if a state does interception toward foreign aircrafts entering its airspace is based on a logic reason. Interception is an action in order to defend the right and sovereignty of the country in airspace over its area if there is any breach on that area. A further explanation about interception action toward breach has been governed in Article 3 Chicago Convention and also in Chapter 3.8 and Appendix 2 Annex 2 of Rule of the Air. $^{19}$

\footnotetext{
${ }^{19}$ Annex 2 of Chicago Convention 1944 consists of 5 (five) parts. Part 1 discusses abput the definition. Part II is about applicability of the rules of the air. Part III is about general rules, next Part IV is about visual flight rules, and the last Part $\mathrm{V}$ is about instrument flight rules. Appendix A Annex 2 of Chicago Convention 1944 explains about signals, while Appendix B is about lights to be displayed by aircraft, replaced with Amendment 24 Annex 3, meanwhile Appendix C and D which each of them explains about rable of cruising level and unmanned free balloons. Nevertheless, the problem of Interception Procedure toward civil aircraft is
}

\section{Cabbotage Principle toward Air Transportation Regulation}

Cabotage means navigation and trade along the coasting trade or petit (cabotage). Nowadays cabotage is promised in commercial agreements across countries which is meant as a trade via sea that is held between two or more harbors in a state (grand cabotage), and it does not belong to the trade with colonial areas of a country. ${ }^{20}$

Based on the sea law analogy, cabotage has been accepted in airspace law through Article 7 Chicago Convention 1944. In this article, it determines that every contracting country has right to reject permission granting to the aircraft passengers carriage, post, cargo, by getting payment or renting, from each place to other places. This article forbids every participant to give exclusive privilege toward the other contracting states or aviation companies belonged to foreign company and accept exclusive privilege (cabotage) from other countries. Cabotage in aviation law is also known as the eight freedom, a right that can be promised based on the willingness of the other countries, that is a right to carry traffic from one place to another in one state areas.

Cabotage, both in sea carriage or air carriage, is a right that is closely related to the exclusive right of a state. In the

explained in Attachment A Annex 2 Chicago Convention 1944

${ }^{20}$ Oppenheim, Lauterpach $\mathrm{t}$ in Mieke Komar, Airspace Law and Spatial Planning Law, (Bandung: Mandar Maju, 1994), 4. 
stipulation of international trade law governing civil aircraft, in Annex about the air service also excludes traffic rights and services related to the traffic rights (excludes traffic rights and all services directly related to their operation). This annex is just valid for repair and maintenance of aircraft, trading and marketing of airline services, courier or management in space and computer reservation system.

\section{Challenges upon the Principles of International Air Law in Globalization Era}

\section{Challenge in Politics}

The challenge in politics for the sovereignty of the aerial region since the assembly of the 52 delegations of the nations in Chicago at 1944. After the end of World War II, the cooperation of the nations in term of civil aviation keeps growing in order to create world peace. The Chicago convention in 1944 becomes the main tool in international standardization for civil aviation under the organizing of ICAO. In term of protecting the freedom and security of plying, the recent civil aviation requires the political awareness of all nations and the international society as a whole. The nation as the main actor is expected to be able to act properly in separated way as well as through the regional alliance. For that, the nations and the regional cooperation indicates the willingness and the capability 264 to adopt and adapt the regulations that protect importance of those who cross the nation borders. $^{21}$

One of the shape of challenge in term of politics upon the aerial region is the presence of those extremists and the terrorism that make the civil aviation as one of their target or the symbol of fighting back. The attack to World Trade Center at 11 September 2001 is one of the most outrageous news for the world. Al Qaeda did the hijacking the plane as the symbol of fighting back upon the main force and authority of economics and political of United State of America.

\section{Challenge in Economics}

Globalization promises upon peace and prosperity in a scale that never happened before. In the other hand, globalization indicates the unfairness, inequality, and "death" from the society and self-government. Globalization in economics is signified by the birth of economic integration (market), multinational-corporation, the flow of capital across country borders, the establishment of international financial body, e-commerce, etc.

a. International Economic Organization

Naturally, the transaction of trading and the international monetary requires the

\footnotetext{
${ }^{21}$ Erwin von den Steinen, National Interest and International Aviation,( The Netherlands: Kluwer Law International, 2006), 10.
} 
international regime in term of facilitating the flow of goods and service freely. This can be realized through the international economics organization, such as World Trade Organization (WTO), the Association of Southeast Asian Nations (ASEAN), International Monetary Fund (IMF), or World Bank. In case of nations having problem in economics and monetary, the concerned country can release some of its sovereignty in economics to the international bodies in order to execute the control upon the policy of its national economics. For example, the policy in securing the monetary and about the Structural Adjustment Programs/SAP. In case of giving urgent loan or postponement of payment, international economics organization execute the SAP to restructure the monetary of a nation.

WTO and ASEAN also liberate the air transport. WTO through its GATS (Annex on air transport services), and ASEAN through AFAS (that later revised to ATISA) has prioritized sectors that one of them is air transport. The liberation of air transport in term of creating a single aviation market for all nations of its membership.

b. Economics Integration

Economics integration is done in various levels, from the multilateral, regional, inter-regional, until the bilateral level. Apart from the sign of trend upon the deal in bilateral integration, the development in two recent decades also signed by the trend of the development of integration and the proliferation of economics integration on the level of regional (Regional Integration Agreement-RIA).

While the form of economics integration in the sector of air transport is also done by several regions of the world apart from the European Union (EU) and the Andean Pact. Since 1995, eight settings has born with the distribution of it around the world (two in United State, one in AsiaPacific, one in Middle East, and four in Africa). Among these deals, seven of them provide the instant liberation or the gradual ones that lead to the access of the market fully. Some of the other potential settings is also still running (in Europe, Northern Atlantic, Southern Pacific and Caribbean). Also in ASEAN, the willingness to shape a single market of international aviation, shown in the scheme of ASAM that consists of several regional deals, some of which are ASEAN MAAS, ASEAM MAFLPAS, and ASEAN MALPAS.

c. Multinational Corporation

The outspread of the major multinational corporation with the monetary power that nearly the same as the invasion of nations and markets are ones of the type of challenge upon the concept of economics sovereignty in the globalization era. This case occurs as the implication from the deal of bilateral trade that contains the asymmetric responsibility or the policy of governmental unilateral that allows the 
excessive flow of foreign capital to the national market and locate the domestic sector in the vulnerable position inside the competition. Multilateral corporation in the air transport sector frequently occurs in Asia, Europe, United State and many more countries.

\section{Challenge in Legal Sector}

a. International Organization and Standardization

One of the international organization in air transport sector is International Civil Aviation Organization (ICAO), as a civil aviation organization that has "the rule making function". As mentioned in article 44 of Chicago Convention of 1944, ICAO has the purpose to develop the principles and techniques of international air navigation and helping the planning as well as the development of international air transport. ICAO established as the international legislator in term of giving the framework of international law for the air navigation service. Every attempts in making the rule (legislative) in the field of air navigation, and more specifically, the provision across the borders of air navigation, firstly must be approached from the international angle to create the international uniformity in the field of civil aviation.

The Chicago Convention of 1994 is the constitution for the ICAO that mentioned from article 43 to 96 . The device 266 regulation of ICAO has some requirements: first, the constitution of ICAO or the main source of law that is the Chicago Convention of 1944. Second, the rules are additional or usually called annexes that commonly consists of "standards" and "recommended practices" 22 . Third, the rule is a guide that is technical and is out of the "standards" and "recommendation", but it is expected to be followed in applying the rules of annex (attachment on annex). Fourth, it is about procedure of Air Navigation Service Operation of Aircraft (PANS-OPS), it is actually the requirement that has the characteristics of an annex, yet due to certain situations it cannot be classified as annex.

b. Jurisdiction of National Extraterritorial Law

\footnotetext{
${ }^{22}$ Standards is the requirements that must be followed for safety reason and if a nation cannot establish one of the requirement in the standards, the nation must notify ICAO. Standards here is every single specification, physical characteristics, configuration, material, performance, personnel, or procedure. The uniformity of application mentioned is needed to run the rule of security of navigation of aerial in international and to all nations of its membership, they can adjust in accordance to the convention; if there are some impossibility in fulfillment, then they must propose the notification to board according to article 38 . While the recommended practice is the requirements suggested to be used by the nations for the better safety in aviation. The recommended practice is all the specification of physical character, configuration, material, performance, personnel, and procedure. Such uniformity of application is needed for the sake of safety, rules and effectiveness navigation in the international aerial fields, and for the nations of its member that will struggle to adjust itself in accordance to the convention. The device of standards and recommendation, however, is rearranged for the convenience or known as appendixes.
} 
Jurisdiction of national extraterritorial law used in several nations based on the national importance, whether it is in economics, military, environment, also security and defense. This jurisdiction is related to the authority to make rules, execute and uphold that certain rules. ${ }^{23}$

\section{CONSLUSIONS AND SUGGESTIONS}

The optimization of using the aerial space, as the asset of development must founded on the harmony of importance in prosperity as well as security. In this case, it needs a correct, comprehensive, and integrated strategy that cover the approach upon law, technology, economics, human resources, socio-culture, environment, security, and defense, organization, institutional, etc. In the context as a nation, the use of sovereignty of a nation upon the aerial space, in the near future, it is needed to revitalize the function of the strong regulation. This can be started by reevaluating the regulations that is continued by the arrangement of the anatomy of the setting that is comprehensive, systematic, careful, effective and also efficient also based on two importance that are prosperity and security.

\footnotetext{
${ }^{23}$ One of the case example is the closure of a the case of Nauvelles Frontieres by the the European Court of Justice, on $30^{\text {th }}$ of April 1986. The other example is the European Union through Council Directive 2003/87/EC, established the rule about emission emitted from the aviation activity that is named European Emission Trading Scheme (EU ETS).
}

\section{REFERENCES}

\section{Journal Articles}

Francesco Gaspari, 'The EU Air Transport Liberalization and Re-Regulation', (2011) 112 International and Comparative Law Review

Hussein Kassim and Handley Stevens, 'Air Transport and The Eropean Union: Europeanization and its Limit', (2010)

\section{Palgrave Macmillan-UK}

John Cobb Cooper, 'Backgrounds of Internasional Public Air Law', (1967)

13 Yearbook of Air and Space Law.

Stepen M. Shrewsbury, 'September $11^{\text {th }}$ and The Single European Sky: Developing Concepts of Airspace Sovereignty', (2003) 68 Journal of Air Law and Commerce, 115.

Stephen D. Krasner, 'Abiding Sovereignty', (2000) 223 International Political Science Review / Revue internationale de science politique.

Thomas Blom Hansen \& Finn Steputat, 'Sovereignty Revisited', (2006) 35, Annual Review of Anthropology.

\section{Books}

Boer Mauna, Pengertian, Peranan Dan Fungsi Dalam Era Dinamika Global, (Bandung: PT Alumni, 2003).

Erwin von den Steinen, National Interest and International Aviation, (The Netherlands: Kluwer Law International, 2006). 
Hans Kelsen, Teori Umum tentang Hukum dan Negara, diterjemahkan oleh Raisul Muttaqien, (Bandung: Nusa Media, 2011).

Ian Brownlie, Principles of Public International Law, Ninth Edition, (Oxford: Clarendon Press, 2008).

Malcolm N. Shaw, International Law, Fifth Edition, (Cambridge: Grotius Publications Limited, 2008).

Mieke Komar, Airspace Law and Spatial Planning Law, (Bandung: Mandar Maju, 1994).

Niels van Antwerpen, Cross Border Provision of Air Navigation Services with Spesific Reference to Europe,
(The Netherland: Kluwer Law International)

Paul Stephen Dempsey and Andrew R. Goetz, Airline deregulation and laissez-faire mythology, Quorum Books, (Connecticut-London: Westport, 1992).

T. Bambang Widiarto, Tinjauan Hukum Udara sebagai Pengantar: Dalam Perspektif Hukum Internasional dan Nasional, (Jakarta: Pusat Studi Hukum Militer, 2015). 